\title{
MARKETING POLÍTICO E ELEITORAL: UM ESTUDO COM DEPUTADOS ESTADUAIS
}

\author{
Richard Medeiros de Araújo ${ }^{1}$
}

\section{RESUMO}

Este paper objetivou compreender como os deputados estaduais, do Rio Grande do Norte, utilizaram os instrumentos de marketing nas suas campanhas eleitorais. Foi realizada uma pesquisa bibliográfica exploratória, descritiva - com uma abordagem qualitativa e quantitativa. Com o universo correspondente a vinte e quatro sujeitos de pesquisa, conseguiu-se uma amostra por acesso de dezenove. A coleta de dados durou trinta dias, considerando as características das atividades dos deputados, tendo sido aplicado um questionário e uma entrevista semiestruturada. Os principais resultados da pesquisa sugerem que a maioria dos deputados são homens e se encontram em uma faixa etária entre 35 e 50 anos. Outro fato verificado na pesquisa é que muitos candidatos, apesar de possuírem nível superior, formados nas mais diversas áreas, não utilizam as ferramentas do marketing por acharem desnecessárias ou mesmo por falta de conhecimento. $O$ conceito de marketing ainda se apresenta obscuro, mas sua instrumentalização ocorre em alguns aspectos de forma deficitária. Conclui-se que a adoção de ferramentas de marketing pelos políticos ainda carece de sistematização gerencial, permanecendo ainda com o caráter da não profissionalização.

Palavras-chave: Marketing político e eleitoral. Ferramentas de marketing. Consumidor. Marca.

${ }^{1}$ UNIFACEX - Universidade Federal do Rio Grande do Norte - UFRN 


\title{
ELECTORAL AND POLITICAL MARKETING: A STUDY OF STATE REPRESENTATIVES
}

\begin{abstract}
This paper aimed at understanding how the Rio Grande do Norte state representatives, used their marketing instruments in their campaigns. A literature search was carried out - an exploratory descriptive research - with a qualitative and quantitative approach. With the universe of twenty-four research subjects it was possible to access a sample of nineteen. The data collection lasted for thirty days, considering the characteristics of the political activities, and a questionnaire and a semistructured interview were applied. The main results of the research suggest that the majority of deputies are men and are included in an age group between 35 and 50 years. Another fact observed in the research is that many candidates, despite having higher education, in several areas, do not use marketing tools because they feel it unnecessary or even for lack of knowledge. The marketing concept still appears unclear, but its instrumentation occurs very poorly in some aspects. We concluded that the adoption of marketing tools by politicians still lacks managing systematization, still remaining the non- professionalization character.
\end{abstract}

Keywords: Political marketing and electoral marketing tools. Consumer. Brand.

\section{INTRODUÇÃO}

Existe um universo mercadológico que se enquadra em outra contextualização que não a empresarial: o eleitoral. Percebe-se que também existe uma linha de trabalho mercadológico com este foco. Podese denominá-lo como marketing político-eleitoral, que não diferentemente do empresarial e pessoal, beneficiam-se dos instrumentos mercadológicos e utilizam os mesmos princípios básicos.

Não se vem acompanhando, nos últimos anos, uma profissionalização maior do marketing políticoeleitoral, como também - necessariamente - uma maior utilização dos instrumentos de marketing e uma nova percepção em relação à própria utilização deste. Em paralelo, existe um interesse dos candidatos a cargos eletivos em trabalhar com "profissionais do mercado", provavelmente, devido à competitividade, por que não dizer hipercompetitividade em busca de um cargo eletivo. Com isso, emerge a necessidade de tornar a campanha político-eleitoral estritamente profissional, almejando resultados positivos, por meio de uma dinamização gerencial própria.

$\mathrm{Na}$ busca pelo sucesso e dentro de uma abordagem mercadológica, surge o interesse, a partir das primeiras eleições diretas, após a queda da ditadura militar, em intensificar a utilização dos princípios mercadológicos dentro do contexto político-eleitoral brasileiro, pois devido à concorrência e ao comportamento dos eleitores, os candidatos a cargos públicos começaram a buscar nas estratégias mercadológicas um melhor desempenho para as suas campanhas eleitorais (FIGUEIREDO, 1994).

Como se pode perceber, o marketing político é um fenômeno capcioso, especialmente, no Brasil. Por um lado, é necessário analisar o "corpo de eleitores", que na sua maioria possui um nível de instrução baixo, os quais utilizam os meios de comunicação de massa como principal fonte de informação sobre os candidatos (televisão, por exemplo). Por outro lado, aparentemente, os políticos tentam trabalhar o composto mercadológico de forma aleatória, independentemente de suas características. Para Figueiredo (1994a) no Brasil, como no mundo, a campanha política profissional - com a utilização de recursos de Marketing como propaganda, promoção e publicidade, aliada aos meios de comunicação sofisticados - 
vem atribuindo volumes maiores de investimentos em campanhas eleitorais, tornando a realidade política brasileira um mercado convidativo.

Nesse contexto, estão os políticos do Rio Grande do Norte que provavelmente utilizam o marketing político-eleitoral e seus instrumentos, talvez de uma forma não-profissional buscando a maximização dos resultados eleitorais. Para se ter uma ideia concreta do acirramento da campanha eleitoral no estado, basta apresentar o número de candidatos ao cargo de deputado estadual em 2002, que de acordo com o TRE-RN foram 229, sendo que apenas 24 (vinte e quatro) passaram a ocupar uma cadeira na Assembleia Legislativa do estado. Com isso, chega-se a um questionamento: como os políticos potiguares eleitos utilizaram os instrumentos do marketing em suas campanhas políticas eleitorais na busca para ocupar um cargo eletivo na Assembleia Legislativa?

\section{Marketing Político e Marketing Eleitoral}

Alguns estudiosos não conseguem distinguir marketing político e marketing eleitoral. Rech (2000) define marketing político como um conjunto de técnicas e procedimentos cujo objetivo é avaliar, através de instrumentos de pesquisa e outros meios, a tomada de decisão, no que diz respeito ao planejamento para alcançar os resultados esperados, ou seja, a vitória. Ribeiro (2002) apresenta o marketing político como uma forma de persuasão, trabalhada primeiramente pelos gregos, especificamente os sofistas (denominado de especialistas do saber), pois estruturaram a forma de persuadir dentro de um contexto sistemático.

Manhanelle (1992) defende que o marketing eleitoral surgiu em paralelo com o marketing. Em sua definição, ele explica que o marketing eleitoral passou por três fases dentre elas a produção, em que os candidatos utilizavam o marketing em sua essência básica, focando em seus trabalhos somente a divulgação, não existindo assim um retorno em termos de contatos com os eleitores.

Na segunda fase, caracterizada como a da propaganda, já havia uma necessidade de veicular as ações políticas - governamentais. A última fase citada pelo autor é a fase do marketing político, a qual é descrita como uma nova abordagem, na qual é necessário conhecer e entender o que a população está querendo ou desejando para só então programar ações sociais capazes de atender ou diminuir os anseios daquela. Manhanelle (1992) descreve que o objetivo do marketing eleitoral consiste em implantar várias técnicas de marketing político e comunicação social integrados de forma a conquistar a aprovação e simpatia da sociedade, construindo uma imagem do candidato que seja "sólida" e que consiga transmitir confiabilidade e segurança à população elevando o seu conceito em nível de opinião pública.

Grandi, Marins e Falcão (1992 p.33) apresentam uma distinção generalista entre o marketing político e eleitoral:

O marketing político está relacionado com a formação da imagem em longo prazo. É utilizado não apenas por políticos, mas também por qualquer pessoa que deseje projetar-se publicamente. Empresários, sindicalistas, apresentadores de televisão, dirigentes de clubes de futebol. A preocupação básica do marketing eleitoral por sua vez é o curto prazo.

Vaz (1995) esclarece que o marketing político existe por um grupo de pessoas ou por uma pessoa que queira angariar um cargo dentro de uma organização, esteja pretendendo ocupar um cargo na presidência de um sindicato, ou então concorrer para uma vaga no conselho comunitário de seu bairro. Isso pode ser visualizado em uma eleição de grêmio estudantil, ou para a presidência de um conselho comunitário. Já Lima (2002) observa que a forma com a qual o marketing político se utiliza das ferramentas técnicas do marketing tradicional de forma sistematizada, não é diferente, o que acontece é uma adaptação 
circunstancial. $\mathrm{O}$ autor ainda aborda que existe uma diferença e significativa entre marketing político e eleitoral, descrevendo com relação à variável tempo, pois o marketing eleitoral se caracteriza por ser momentâneo, situacional. Enquanto o marketing político é amplo quando observado pela variável espaço, uma vez que ele pode ser utilizado em organizações públicas e privadas.

De acordo com Marland (2003), dentro do conceito do marketing, os partidos e políticos são enquadrados como entidades que compartilham características como bens e produtos, são fornecedores de bens e serviços especializados, sendo o ambiente de marketing competitivo e distinto, e as formas de aquisição por parte dos eleitores e sociedade dependerão da forma como eles irão perceber os benefícios que terão no futuro com a vitória de determinado candidato ao cargo público.

Já existe uma visão do marketing político e eleitoral apresentada por Collim e Butler (2001) que defende que o marketing eleitoral não existe, é percebido somente durante as campanhas políticas eleitorais, quando se conhece o chamado marketing político dentro de uma nova denominação, chamada de campanha permanente. Para esses autores um político, independente do cargo que ocupa, ou do cargo pleiteado, deve ter em mente a seguinte observação: "estou sempre em campanha, não posso esquecer que a todo momento, minhas atitudes, comportamentos e comunicação estão sendo alvos de análises pela sociedade e pelos formadores de opinião". Isso significa afirmar que os erros e acertos interferirão no futuro em alguma competição que venha a participar, dependendo dos cenários, agregarão valor ou não.

O que acontece com a maioria dos políticos é a chamada "miopia", pois, estes sofrem dessa anomalia mercadológica, uma vez que consideram a importância do marketing somente no período pré-eleitoral, seja desenvolvendo campanhas publicitárias ou fazendo a agenda da logística de aparições e reuniões. Outro ponto destacado na discussão está na necessidade do marketing político e eleitoral ser estudado cientificamente na academia, sendo um caminho para que se tenha um maior e mais qualificado arcabouço teórico.

Ribeiro (2002) apresenta um novo composto característico para as campanhas futuras:

- velocidade / instantaneidade - as campanhas estão sendo realizadas em espaços muito curtos de tempo;

- centralidade da informação e do conhecimento - necessidade de trabalhar a campanha dentro do contexto da gestão da informação;

- diminuição do papel dos militantes e do pessoal com baixa qualificação técnica;

- desenvolvimento e aperfeiçoamento dos processos de busca de informações; integração sistêmica das informações e comunicação: o foco na rede de informações entre fornecedores (surgimento de uma estrutura horizontalizada);

- desmassificação das campanhas, segmentação de mercado;

- meios de comunicação interativos, utilização da Internet ;

- nova estrutura organizacional a horizontalização e a flexibilização;

- televisão que continua a ter influência, debates televisionados ganham força;

- enfraquecimento dos partidos políticos.

Dentro desse novo contexto, o marketing político e eleitoral se destaca, como ferramenta construtora de relacionamentos não mais voltada somente para ganhar a eleição, mas antes de tudo firmar a posição do candidato no mercado eleitoral e na sociedade. É interessante apresentar a visão que Ribeiro (2002) mostra, ao dizer que a maior crítica feita ao marketing político está relacionada à teoria da espetacularização, seu principal expoente é o francês Roger-Gerard Schwartzenberg.

Essa teoria é embasada pelo marxismo, no qual a imagem que se faz do político dentro do contexto político, não pode ser colocada de lado em relação às estratégias de marketing, ou análises sociais políticas. Essa "mágica" que é apresentada ilude o eleitor/ cidadão, manipula-o e o seduz. Na verdade, a crítica 
está na imagem projetada do candidato através dos instrumentos de marketing, mas que na verdade muito destes não mantém esta imagem após o período eleitoral.

O composto do marketing político não difere do mix de marketing em sua essência, as interpretações são diferentes, visto que são analisados em contextos distintos, como segue abaixo de uma coletânea adaptada de Rech (2000), Figueiredo (1994) Kotler (2000), Richers (2000) e Manhanelle (1992). Dentro do composto mercadológico do marketing eleitoral devem ser considerados o que os autores Grandi, Marins e Falcão (1992) apresentam, expresso no quadro 1.

Quadro 1 - Fatores de composição do candidato

\begin{tabular}{|c|l|}
\hline POTENCIAL PRÓPRIO & $\begin{array}{l}\text { Capacidade de liderança } \\
\text { Habilidade de discurso } \\
\text { Carisma }\end{array}$ \\
\hline FATORES INTERNOS DE PRESSÃO & $\begin{array}{l}\text { Grupo Político } \\
\text { Grupo de financiamento }\end{array}$ \\
\hline FATORES EXTERNOS DE PRESSÃO & $\begin{array}{l}\text { Eleitores } \\
\text { Adversários }\end{array}$ \\
\hline
\end{tabular}

Fonte: Grandi, Marins e Falcão (1992)

Todas as variáveis expostas no quadro devem ser ponderadas e analisadas estruturalmente, considerando os cenários políticos eleitorais possíveis de se concretizar. Sendo necessário também que os concorrentes sejam acompanhados, para identificar as disfunções de comportamento, construindo duas linhas de frente de trabalho que deveriam evitar falhas ou usar delas para uma ação eleitoral, respeitando os preceitos éticos.

\section{Os Instrumentos de Marketing Político - Eleitoral}

O marketing é dotado de diversas ferramentas que auxiliam os gestores a programar as ações do planejamento, baseados nos objetivos macro e micro organizacionais. Concomitantemente, a busca pelos resultados positivos cobrados pelas diretorias das organizações, candidatos a cargos eletivos, organizações não governamentais, fazem com que os gestores mercadológicos se utilizem das ferramentas estratégicas disponíveis.

Tecnicamente, Grandi, Marins e Falcão (1992) afirmam que fora apenas em 1954, na campanha para a prefeitura de Belo Horizonte, que se utilizaram das primeiras ferramentas de marketing eleitoral no Brasil, suportado pela definição de uma estratégia implementada de forma profissional pelo publicitário João Moacir de Medeiros. Na percepção de Rech (2000), o marketing eleitoral emprega ferramentas técnicas de marketing político somado com a comunicação social integrada de forma a conquistar a sociedade elevando o conceito do candidato, dentro de um contexto moral e ético.

Kotler (1994) apresenta uma técnica, mas que isso, é uma forma de desenvolver a administração do marketing, de forma totalmente interdependente, buscando infinitamente a integração necessária para o alcance dos objetivos com qualidade. O marketing de imagem pode ser adaptável para uma situação política eleitoral, em que o candidato define com que imagem quer que seu público e sociedade o perceba, determina que tipos de atrações podem ser contratadas (como participações em eventos sociais etc.), define a infraestrutura, o pessoal envolvido na implementação e outros suportes necessários para 
subsidiar a construção da imagem e o desenvolvimento do planejamento da campanha, por exemplo. $\mathrm{O}$ autor apresenta 4 tipos de imagens que também podem ser adaptadas para a ênfase deste trabalho: Imagem positiva; Imagem pobre; Imagem negativa e Imagem mista.

Ribeiro (2002), afirma que a estruturação do candidato com vistas à persuasão, depende da utilização de provas apresentadas nas quais o candidato deve passar credibilidade, a partir de suas credenciais morais, para somente assim conquistar a confiança dos eleitores, criando disposições nos eleitores. Rego (1985) apresenta o que ele define, como o ABC do Marketing Político (ilustrado no quadro 2) que poderia dependendo do momento ser denominado de marketing eleitoral.

\section{Quadro 2 - ABC do Marketing Eleitoral}

\begin{tabular}{|l|l|}
\hline Definição de uma estratégia de marketing adequada & Arregimentar grupos para trabalhos voluntários \\
\hline Definição dos segmentos alvo e periféricos de & Formar uma ampla base de alianças \\
\hline Saber ler o maior ambiente e identificar os riscos e & Escolher equipe de profissionais de assessores \\
\hline Desenvolver um conceito e uma identidade & Ter disposição e método de trabalho \\
\hline Ganhar projeções em entidades representativas & Conhecer as pesquisas de opinião \\
\hline Ganhar a confiança do partido & Desenvolver boa presença em comícios \\
\hline Definir com muito cuidado a estratégia de & Prepara-se para os debates na mídia em geral \\
\hline Preparar um bom plano e um eficiente cronograma & Alcançar o ponto de equilíbrio em todos os \\
\hline Conseguir um sólido esquema de financiamento & Convergir os enfoques, apelos e os materiais para um \\
\hline
\end{tabular}

Fonte: Adaptado de Rego (1985)

Semenik e Bamossy (1995) e Kotler (1996) definem o marketing direto como campanhas de marketing que utilizam vendedores ou um meio impessoal, como o correio, e-mail ou telefone, para solicitar pedidos dos consumidores, no local que residem ou trabalham. O marketing direto utiliza a mídia para transmitir a mensagem, solicita a tomada de decisão pelo destinatário da mensagem e colhe, imediatamente, sua resposta. Entende-se, também, o marketing direto como o canal de distribuição mais curto com que a empresa conta para lidar com o consumidor, ou marketing de varejo. Pode-se dizer que os esforços mercadológicos do marketing direto estão dirigidos a levar a empresa para a casa ou escritório do consumidor.

Nunes (2000) apresentou uma pesquisa de opinião, com investigações dentro do contexto coletivo, no qual foram utilizados questionários. A pesquisa foi dividida em duas abordagens a quantitativa e qualitativa. A qualitativa possui um caráter exploratório construtivo, abordagem com uma fonte de informações orientativas para os candidatos, pois as técnicas deste tipo de abordagem lidam com aspectos subjetivos, buscando compreender as motivações que fazem as pessoas reagirem, entenderem seus sentimentos com relação as mais diversas variáveis, dentro e fora de um determinado contexto analisado pelo pesquisador.

A quantitativa buscou o aspecto da medição, a quantificação de aspectos definidos a priore, a sua natureza é confirmatória e/ou dedutiva e tem o instrumental estatístico como ferramenta para permitir, quando adequadamente utilizado, a definição de amostras que permitam projetar ou generalizar os resultados encontrados para todo o universo ou população, pesquisado. Para Mattar (1994), na pesquisa quantitativa os dados são obtidos de um grande número de respondentes, usando-se escalas, 
geralmente numéricas, os quais são submetidos a análises estatísticas formais. Segundo Nunes (2000), embora tenham construções analíticas distintas, dependendo dos objetivos que se tenham, elas podem ser complementares.

Machado (1998) observa através de exemplos práticos, a respeito da finalidade das pesquisas, afirmando que tudo depende da sua natureza, dentro do contexto do marketing político e eleitoral. As pesquisas quantitativas contribuem para: Um diagnóstico do posicionamento no ranking de candidatos; Buscar entendimento das intenções de voto; Fazer levantamento do nível de envolvimento do eleitorado; Tentar identificar as razões de aceitação e rejeição dos candidatos; Analisar as variáveis que influenciam na decisão do voto; e investigar os nichos de maior visibilidade dos candidatos.

As pesquisas qualitativas são úteis para aprofundar analiticamente as discussões sobre: a imagem dos candidatos interpretada pela sociedade; estudar os anseios e desejos do eleitorado (consideram os aspectos político, socioeconômico e cultural etc.); a qualidade da argumentação (como o eleitorado entende o candidato ou o político); capturar como está o elo de sintonia dos programas eleitorais; e projeções e expectativas de governantes.

Como afirma Lima (2002), de nada adianta se utilizar desta ou daquela ferramenta como a internet, por exemplo, não se preocupando na etapa do planejamento estratégico do marketing eleitoral, em ter os objetivos bem definidos de campanha (e um desenho estrutural completo da campanha eleitoral), definir também os resultados que cada uma das ferramentas pode oferecer e paralelamente avaliar todas as ações.

Então, Sterne e Priore (2001) apresentam as vantagens de utilizar essa ferramenta, seja através da disponibilização de uma home page, ou apenas de um contato eletrônico, que foram adaptados para o contexto do marketing político e eleitoral: Atinge camadas fortemente formadoras e multiplicadoras de opinião; se trata de mídia com custo absoluto e relativo ainda muito baixo, oferecendo alto índice de retorno sobre investimento em comunicação; oferece o que mídia alguma oferece a interatividade imediata, potencializando o efeito da mensagem publicitária, se bem criada e produzida; divulgações e acesso ’á interação com públicos alvos específicos; captação de informações criativas e estratégicas.

E no sentido amplo da proposta, Godin (2000) apresenta a necessidade de o Marketing de Relacionamento transcender e entrar no meio virtual, onde a busca pela lealdade se torna mais complexa. Um candidato a cargo público pode utilizar dessa ferramenta na captação de ideias, para aplicação de pesquisas quantitativas e pesquisas de acompanhamento e tendências. Pode através dela mostrar para a população as propostas do candidato, buscando identificar quais as necessidades emergentes de cada bairro, para saber onde o político vai atacar nas suas oratórias etc.

Geralmente, o telemarketing montado pelos candidatos a cargos eletivos são ativos, ou seja, eles mantêm uma estrutura de pessoal ligando para os eleitores, por isso, neste momento é preciso que se tenha a formação de uma equipe de trabalho (pessoal treinado e antes de tudo pessoas educadas e sérias), em que saber ouvir e a capacidade de conversar amigavelmente se destacam. Geralmente, esse tipo de instrumento quando é utilizado demanda um maior aporte de recursos, ou a necessidade de parcerias com outras organizações (KOTLER,1996).

As campanhas por TV, assim como os candidatos em debates, utilizam matérias impressas (sobre si ou sobre seus adversários) como documentos para provar um ponto de argumentação. Manchetes, fotos, trechos das matérias que são destacados para leitura no vídeo, são alguns exemplos de técnicas usadas na TV para documentar argumentos.

Publicidade significa exposição não paga da empresa ou seus produtos à mídia. Por um lado, devido à sua falta de controle estratégico, ela dominará o mix de comunicação. Por outro, ela pode ser um fator auxiliador na construção de imagem e no aumento da conscientização de produtos ou empresas. Tipicamente, as empresas preparam press releases (notícia distribuída aos meios de comunicação para ser 
divulgada gratuitamente) relativos a desenvolvimento de novos produtos, vendas e lucros registrados no trimestre, novos investimentos de capital e programas de expansão, e outros eventos similares importantes.

Outro item do mix de comunicação é o profissional de relações públicas que cuida da elaboração de estratégias de comunicação, buscando aumentar a popularidade do candidato, e mantê-la em uma linha sem deslizes, do ponto de vista de marketing. Na realidade, o que acontece nesse momento a função do marketing político sendo desenvolvida a partir da atuação do relações públicas, que expande o seu campo de ação em decorrência das necessidades da campanha e dos recursos limitados.

Mesmo possuindo uma característica de visão macro da comunicação, o Relações Públicas atua no marketing político/eleitoral, principalmente, sob os aspectos: o da Comunicação Dirigida e o da Auditoria de Opinião. No primeiro, porque em qualquer campanha de marketing político/eleitoral faz-se necessário, num dado momento, direcionar as ações de comunicação para públicos mais específicos, ou seja, para os formadores de opinião.A segunda é uma função elaborativa afirma Kunsch (1997), pois é um processo de exame analítico e pericial que tem por objetivos chegar a um balanço das opiniões, após realização de um levantamento cuidadoso de informações junto aos públicos de todos os segmentos de interesse, levantar o perfil real da instituição (do partido ou candidato), seu nível de conhecimento e aceitação, grau de satisfação de seus públicos (eleitores) além de ser a auditoria também um importante instrumento para detectar conceitos e preconceitos emitidos pelo público.

O que deve ser evitado é o que os autores Grandi, Marins e Falcão (1992), chamam de erro de comunicação, no qual os candidatos na perspectiva de responder às observações dos concorrentes ou até querer expor alguma informação importante comentem falhas em veicular, respostas sem antes analisar os caminhos que serão utilizados para tal, por isso, a necessidade de se ter um staff de comunicação, que atente para esses estudos.

Não diferentemente de qualquer atividade organizacional, uma campanha eleitoral, além da operacionalização, deve ser elaborado um planejamento de marketing eleitoral em paralelo com o operacional. Sendo este o suporte e uma ferramenta de acompanhamento estratégico, subsidiando o candidato a desempenhar habilmente seus diversos comportamentos, assim como buscando informações para fazer os realinhamentos necessários, no que diz respeito ao comportamento dos eleitores (percepções, ideais etc.). Na verdade, o planejamento de marketing eleitoral deve conciliar a proposta do candidato com a real necessidade dos eleitores, considerado todos os recursos disponíveis, somado ao histórico político e os instrumentos de marketing eleitoral.

Partindo dessa premissa, conforme Redondo (1993), o planejamento deve ser composto por diversas variáveis, mas nunca deve desconsiderar a figura do político antes, durante e após uma campanha eleitoral, ele afirma que é uma pessoa pública independente de sua vitória ou não, se faz necessário continuar cuidando e administrando sua imagem na sociedade. Principalmente, se estiver dentro daquela filosofia de campanha permanente, defendido por Collim e Butler (2001). Para que o planejamento de Marketing Eleitoral se concretize existem as metas e os meios que precisam ser bem elaborados. Faz-se necessário, acompanhar os concorrentes dos candidatos, identificando suas falhas, pontos fortes e fracos, e além de tudo acompanhar onde estão sendo implementados os trabalhos deles, para que possa ser traçada uma estratégia de ação. Oliveira (2000) fala da estratégia de difusão (único foco) ou segmentação (vários focos, abordado no item segmentação e posicionamento), o candidato deve optar por uma dessas estratégias, assessorado pelo administrador de marketing da campanha. No quadro 3, é apresentado uma estrutura proposta por Oliveira (2000), que destaca os instrumentos de marketing que os políticos e/ou candidatos têm acesso para desenvolver as campanhas com um menor grau de dificuldade. Várias dessas ferramentas foram explicitadas anteriormente, as demais são instrumentais que corroboram para a implementação eficiente da gestão do marketing eleitoral. 
Quadro 3 - Descrição dos instrumentos de marketing político e eleitoral

\begin{tabular}{|c|c|}
\hline Instrumento/ Ferramenta & Objetivo \\
\hline Página na Internet & $\begin{array}{l}\text { Divulgar ideias do candidato e seu partido, interagir com o } \\
\text { eleitor; }\end{array}$ \\
\hline $\begin{array}{l}\text { Pesquisas Quantitativas e } \\
\text { Qualitativas }\end{array}$ & $\begin{array}{l}\text { Conhecer opiniões dos eleitores sobre a conjuntura do país } \\
\text { e a imagem do candidato; }\end{array}$ \\
\hline Projeto integrado de comunicação & Uniformidade nas mensagens; \\
\hline Marketing de relacionamento & Aproximar-se o máximo do eleitor; \\
\hline Comerciais & Divulgação da imagem ; \\
\hline Estudo de típia & Cria um slogan de impacto, simples, objetivo e atraente; \\
\hline Equipe de monitoração & Acompanhar a relação mídia e candidato; \\
\hline Telemarketing & $\begin{array}{l}\text { Instrumento estratégico atinge residências e serve de } \\
\text { suporte para as outras ferramentas; }\end{array}$ \\
\hline Outdoors & Divulgar o candidato /político; \\
\hline Jingle & Divulgar o candidato; \\
\hline Reuniões & Obter apoios e mostrar resultados; \\
\hline $\begin{array}{l}\text { Showmícios, caminhadas, e } \\
\text { viagens }\end{array}$ & Criar um elo com a população; \\
\hline Adaptação da linguagem & A busca pela aceitabilidade; \\
\hline Carretas e passeatas & Aproximar-se do eleitor; \\
\hline
\end{tabular}

Fonte: Adaptado de Oliveira (2000)

Assim como o desenho do planejamento é importante, a utilização de um sistema de gestão gerencial eleitoral também. Dentro do universo de uma campanha eleitoral, em que os dados são muitos e na maioria das vezes desorganizados, faz-se necessário a constituição do SIG - Sistema de Informações Gerencial. A análise da literatura confirma que existem pesquisas visando à profundidade do conhecimento, criação, armazenamento, transferência, e aplicação de sistemas de Informações nas instituições, conforme apresenta Graeml (2000).

$\mathrm{Na}$ estrutura política a utilização de sistemas de informações, conectados ou não na grande rede, deve existir, com vistas a suportar e subsidiar as ações eleitorais. Na ponta desse sistema está o candidato, que deve receber somente as informações necessárias e úteis, sendo esta uma das atividades dos assessores e dos desenhistas do sistema. Tal sistema não pode ser fechado, mas sim trazer informações que trabalhem diretamente com as ações eleitorais no sentido de buscar imputações acertadas, seja o número de eleitores cadastrados naquele bairro, suas principais necessidades/ desejos, potencial de voto etc (REDONDO, 1993). 


\section{METODOLOGIA}

Para Lakatos e Marconi (1986) o método é definido como uma forma de proceder ao longo de um caminho. Na ciência, os métodos constituem os instrumentos básicos que norteiam o pensamento de maneira sistemática, traçam de modo ordenado a forma de proceder do cientista ao longo de um percurso para alcançar um objetivo. Na pesquisa, fora adotada uma abordagem qualitativa e quantitativa, devido ao foco do estudo.

O tipo de pesquisa adotado foi o exploratório-descritivo, o qual deu acesso ao pesquisador para uma melhor compreenssão sobre o tema, visando capturar os conhecimentos necessários à fundamentação da pesquisa. Na concepção de Vergara (1998), esse tipo de pesquisa tem como principal objetivo tornar algo intangível em tangível, justificando os motivos, com o propósito de contribuir de alguma forma para a ocorrência de determinado fenômeno. Uma pesquisa exploratória se caracteriza de acordo com Gil (1987), por envolverem entrevistas com pessoas que tiveram experiências anteriores (relacionado com o objeto de estudo) e um aprofundamento bibliográfico no intuito do pesquisador se dotar de um suporte teórico.

Segundo Oliveira (1997), não se deve nas pesquisas em geral, utilizar somente uma técnica e um método, ou aqueles que se conhece, mas sim utilizar técnicas e métodos que sejam necessários para a implementação da pesquisa. Assim, foi adotada também a análise de conteúdo como técnica qualitativa, a qual para Roesch (1999) é uma ferramenta qualitativa que tem o propósito de analisar os transcritos gravados durantes as entrevistas.

A pesquisa de campo para a coleta de dados foi realizada no estado do Rio Grande do Norte. A coleta teve uma duração de 30 dias (Junho de 2005), uma vez que os políticos possuem diversas obrigações e várias atividades, a coleta se deu no seu reduto de trabalho. Na visão de Roesch (1999), a população alvo do estudo é um grupo de pessoas ou empresas que interessa entrevistar para o propósito específico de estudo. Atentando na hora de defini-la, levar em consideração algumas variáveis como o tempo dos sujeitos de pesquisa, o orçamento do investigador e a capacidade de processamento dos dados, sendo necessário adotar uma amostra representativa do universo.

No caso do estudo, o universo da pesquisa foi constituído pelos deputados estaduais do Rio Grande do Norte, que são em 24 (vinte e quatro), que exerceram seus mandatos entre 2002 e 2006. Mas apenas 19 (dezenove) sujeitos foram entrevistados, devido a contingências diversas, tem-se assim uma amostra não probabilística por acesso. Para fins de análise os sujeitos de pesquisa foram nominados por letra.

Para a coleta de dados foram aplicados dois instrumentos de coleta um questionário e um roteiro de entrevista - em que o questionário fora um Instrumento adaptado de Oliveira (2000), para levantar dados como escolaridade, idade, partido político, instrumentos de marketing etc. , seguido concomitantemente da realização de uma entrevista semiestruturada acompanhada de gravação com a autorização de todos os pesquisados, cuja base foram os autores Machado (1998), Oliveira (2000), Salles (2000), Nunes (2000) e Rego (1985) .

Já que se trabalhou com a análise de conteúdo, enquanto método qualitativo de análise, a gravação ou relato é essencial. Todas as entrevistas foram marcadas com antecedência pelo pesquisador com os sujeitos da investigação, estabelecendo um consenso com relação a horários e datas, esclarecendo o objetivo do estudo e a sua importância. A pesquisa teve um caráter racional em relação à postura do pesquisador, procurando não influenciar nas respostas dos sujeitos de pesquisa. Foi necessário em média uma hora para a aplicação dos instrumentos da pesquisa. Para Roesch (1999, p.39) "em entrevistas semiestruturadas utilizam-se questões abertas, que permitam ao entrevistador entender e captar a perspectiva dos participantes da pesquisa."

Durante as entrevistas, os sujeitos foram comunicados que poderia surgir a necessidade de haver um segundo ou até terceiro encontro com o pesquisador, devido à amplitude do trabalho proposto. $\mathrm{O}$ 
procedimento utilizado, no tratamento de dados, seguiu a seguinte linha: os dados colhidos de forma, quantitativa, foram tratados com a utilização do Excel, seguindo da análise de conteúdo no contexto qualitativo do material gravado nas entrevistas a qual na visão de Rey (2002) e Bardin (1977) é uma técnica que se apoia na codificação de informações colhidas dos sujeitos de pesquisa em categorias definidas com o objetivo de dar sentido ao material a ser estudado, considerando o texto como um objeto e o pesquisador adotando uma postura analítica.

\section{ANÁLISE E DISCUSSÃo DOS RESULTADOS}

\section{Perfil dos Deputados Estaduais (2002-2006)}

A maioria na Assembleia Legislativa do estado do Rio Grande do Norte são pessoas do sexo masculino, ou seja, $89 \%$ (oitenta e nove por cento). Permanecendo quase que inalterado esse cenário, dentro do contexto histórico do estado. Migrando para o quesito faixa etária dos deputados estaduais, pode-se considerar que, quase $80 \%$ dos consultados estão na faixa etária entre 35 anos e acima de 50 anos. Ficando a parcela jovem da assembleia com pouca representação, em torno de $16 \%$. Fazendo uma relação entre a faixa etária e o sexo, percebe-se que mais de $75 \%$ dos deputados da assembleia são homens e estão com idade média acima de 50 anos. As deputadas pesquisadas estão enquadradas na faixa etária entre 18 e 35 anos, consideradas as mais jovens da casa legislativa.

A terceira parte analisada no perfil dos pesquisados, foi o partido político, na intenção de conhecer em números a representação de cada legenda na Assembleia Legislativa. Encontrou-se um equilíbrio, se destacando o PMN e o PSB com $20 \%$ cada um. Seguido do conhecimento sobre os partidos políticos, também foi identificado o tempo de vida pública que cada deputado tinha, dentro da perspectiva da história deles, sua aparição no meio social e os trabalhos que o destacaram, $74 \%$ dos deputados pesquisados possuem mais de 08 anos de anos de vida pública. Se diluindo em outros dois intervalos $26 \%$, que se encontram entre 4 e 7 anos. Dentro do contexto eleitoral, percebe-se, que $36 \%$ dos deputados pesquisados, já possuem três ou mais mandatos, o que pode significar, que conseguem desenvolver algumas estratégias de marketing, de forma não estruturada, mas que contribuem de alguma maneira para a sua permanência no poder, ou melhor, que tenham mais de um mandato na Assembleia Legislativa do RN.

Outra informação importante é que 57\% dos deputados (2002 a 2006), não vêm de outro mandato (vereador, prefeito etc), conseguiram ganhar o pleito, sem possuir experiência nem no executivo ou legislativo anteriormente. O quantitativo de $26 \%$ dos pesquisados já tiveram experiência anterior no legislativo, como vereadores. O que facilitou a articulação para suas respectivas campanhas para deputados e culminou na vitória.

No item grau de instrução, verificou-se que a maioria dos entrevistados possui nível superior, o correspondente a $60 \%$. Ainda $20 \%$ deles possuem somente segundo grau. Na sua maioria, são formados em áreas humanas e de saúde. Dos pesquisados apenas $15 \%$ continuaram os estudos partindo para PósGraduação, deste grupo $10 \%$ concluíram o curso e $5 \%$ estão em processo de conclusão. O último item tratado no grupo de questões relacionadas com o perfil foi o número de assessores que estes tinham dentro da Assembleia, auxiliando nas atividades diárias, uma vez que se sabe, que além de atender à população, existem, atividades específicas, como estudo de projetos de leis e requerimentos em geral. $38 \%$ dos pesquisados possuem mais de 10 assessores cada um, $50 \%$ deste grupo não possuíram mandatos anteriores e $50 \%$ já foram vereadores, prefeitos ou governadores.

Dentro ainda desse grupo de pesquisados, encontra-se um item que merece ser destacado o não monitoramento dos concorrentes no período eleitoral, correspondendo a 100\% desta amostra. Ampliando a 
discussão, pode ser levantado outro questionamento sobre assessores, não existindo nenhuma preocupação com o estudo, pelo menos no período eleitoral, das fraquezas e forças dos adversários. Outra observação é que $90 \%$ desse mesmo grupo, que possui uma gama de assessores, também não se preocupam em ter um cadastro de políticos parceiros, sejam vereadores, prefeitos, líderes etc, que podem vir a auxiliar em qualquer pleito, no contexto da rapidez e agilidade nas ações eleitorais sejam na capital do estado ou nos municípios do interior.

Os assessores conforme descreve Figueiredo (1986) devem estar informados de tudo o que acontece com o candidato/deputado e qualquer fato que esteja relacionado a ele. No sentido de orientá-lo nas atitudes e comportamentos perante as mais diversas situações, tentando reverter os fatos de maneira positiva e aperfeiçoando a imagem do postulante. Qualitativamente, fora questionado aos candidatos como eles escolheram seus assessores, que tipo de requisitos devem possuir. Logo abaixo segue as principais falas transcritas.

"... Geralmente quem trabalha comigo aqui na assembleia trabalha na campanha também. Mas a escolha é mais baseada em competências e na amizade no relacionamento de confiança..."; Sujeito F

'...é importante que além de competentes e profissionais eles sejam grandes amigos. Essa é uma fórmula que dá certo..."; Sujeito $\mathbf{J}$

' ...Não tivemos profissionais específicos na campanha, mas na assembleia contratamos pessoas pela competência nada de indicação, não trabalhou bem, rua..."; Sujeito D

'... Capacidade e competência aliada a uma estratégia de relacionamento, somado a humildade sempre... "; Sujeito L

"...A minha equipe é composta por amigos de longas datas, o que temos uma relação de confiança muito grande, claro que nós utilizamos dos aspectos técnicos..." Sujeito M

Percebe-se que existe uma preocupação em se ter pessoas competentes, mas também que se tenha o que eles denominam de "laço de amizade e confiança", até porque na assembleia, geralmente é onde acontece o atendimento à população, desde uma autoridade até um simples cidadão, e o assessor é a imagem prévia do deputado. Para a maioria dos entrevistados, o papel do chefe de gabinete (enquadrado pelos próprios deputados, como a pessoa mais próxima a eles) deve filtrar tudo antes de chegar qualquer solicitação, informações ou outros aos investigados.

\section{Concepção sobre Marketing no Contexto Eleitoral}

Nesse grupo de questões, foi explorado como os deputados estaduais utilizaram as ferramentas/ instrumentos de marketing eleitoral, na última campanha em 2002. Se dividindo em vários subgrupos de questionamentos, que abordam desde a estratégia nas ações eleitorais, passando pelo composto promocional e desembocando no posicionamento e na segmentação de mercado. Primeiramente, foi perguntado como eles definiram as suas ações eleitorais para a campanha que aconteceu em 2002.

Conforme afirmam Churchill e Peter (2000) deve-se buscar a combinação estratégica de ferramentas usadas para criar valor para os clientes (eleitores) e como consequência atingir os objetivos do candidato. Parte-se do pressuposto que o candidato define, primariamente, as estratégias eleitorais, que subsidiará a campanha eleitoral. Schewew e Smith (1982) ratificam isso ao afirmar que o marketing e seu composto 
devem sempre ser desenvolvido e implementado dentro de uma filosofia de sistema integrado.

Dando ênfase ao que Middleton (2005) defende ao afirmar que o marketing deve se encontrar no estágio relacional. Isso é importante dentro do cenário político, uma vez que se sabe das flexibilizações existentes, das maleabilidades, das mudanças entre as pessoas e suas escolhas eleitorais. Dento dessa situação percebe-se que a importância dada pelos deputados (a épocas, candidatos), para o que os eleitores dizem, é muito frequente, $73 \%$, deles afirmaram considerar essa variável no momento de definir as ações eleitorais.

No mesmo raciocínio, também se identificou uma importância inexpressiva dada aos concorrentes, na verdade é como se cada candidato não se preocupasse com os outros candidatos, o que é prioridade na área empresarial, no contexto eleitoral, é desconsiderado. Isso se ratifica com apenas uma frequência de $10 \%$ no item busca pelas informações sobre os candidatos concorrentes. Assim, não é denotada uma vontade de desenvolver o que Porter (1990) chama de diferenciação competitiva, a busca pela vantagem competitiva, que facilite os trabalhos e as ações durante a campanha eleitoral. 89\% dos deputados que afirmaram considerar as necessidades/ desejos dos eleitores como um suporte na decisão das ações eleitorais, já desmistifica a ideia de que, o planejamento da campanha mercadológica eleitoral, não segue os passos da lógica cliente. Ao mesmo tempo 73\% recebem sugestões dos eleitores para adequar as propostas, mostrando a proximidade com o prospect eleitoral.

Objetivando conseguir captar como era construída a diferenciação durante a campanha eleitoral, e até após o término desta, $89 \%$ dos deputados entrevistados afirmaram que procuram desenvolver uma marca específica junto aos eleitores. Talvez através de comportamentos, ações e atitudes que o destaquem durante o pleito, fazendo com que os eleitores fizessem uma associação entre aquela ação, por exemplo, e o candidato. Dos $26 \%$ dos candidatos que afirmaram criar mecanismos de comunicação com a finalidade de manter seus nomes sempre em ascensão são homens e $70 \%$ já tiveram mandatos anteriores como deputados e vereadores.

Isso sugere que quanto maior a vivência em um cargo eletivo, mais se dá importância à necessidade de estar sempre em evidência. 31\% disseram que, para diferenciar-se dos concorrentes, se preocupam em mostrar o desempenho político nas assembleias (para aqueles que já eram deputados). E 47\% afirmaram que apresentam os benefícios alcançados para a comunidade, não somente como pessoas que já ocupam cargos no legislativo, mas como seres de comunidade, que foram líderes, presidentes de conselhos comunitários etc.

\section{O Composto Promocional: O Mundo dos Deputados}

No processo eleitoral, essa estratégia é disseminada, pois coloca o objeto a ser promovido, em todos os lugares, sendo nas casas através da televisão, revistas, rádio, Internet ou mais próximo ainda dos eleitores, nas ruas através de outdoor em locais pré-definidos, painéis e etc. Ao se tratar da utilização das revistas e outdoors durante a campanha política em 2002 32\% sempre utilizou, desse grupo todos possuem ensino superior completo. Outro grupo de 32\% afirmou nunca terem utilizado desse tipo de ferramenta na campanha, uma curiosidade, é que todos são homens e estão acima de 50 anos de idade. Sendo o argumento do não uso a falta de recursos, como sendo o fator impeditivo da adoção desta prática. Outra informação que merece ser destacada é que $95 \%$ dos que sempre utilizaram ou quase sempre utilizaram revista e outdoors, estão focados no item apresentado anteriormente: criar um mecanismo de comunicação que o mantenha sempre em evidência, ou seja, existe uma preocupação prévia em se manter na mente das pessoas.

Fora questionado aos deputados quanto à utilização de propaganda em ônibus, tiveram 15\% que afirmaram ter utilizado esse tipo de ferramenta, uma vez que a legislação eleitoral vigente não permite 
esse tipo de ação. O quantitativo de $84 \%$ afirmou que nunca utilizou, sendo os motivos os mais variados possíveis, desde a falta de recursos até o fato de não acharem necessário. Aqui verifica-se que a adoção desta prática aconteça no interior do estado, uma vez que, nestas localidades a fiscalização da justiça eleitoral não é eficaz.

Quanto às ações da propaganda em aeroportos e terminais rodoviários, tem-se que aqueles que afirmaram nunca terem utilizado dessa forma de propaganda de sua imagem e sua campanha representa $78 \%$ dos entrevistados, desse grupo $31 \%$ não acharam esse tipo de ação necessária, e $31 \%$ afirmaram que faltaram recursos na época. Ao se tratada da propaganda em jornais e outras correspondências (denominado como outros impressos em geral), $75 \%$ dos entrevistados estão entre os que sempre utilizaram e/ou quase sempre utilizaram dessa forma de promoção durante a campanha eleitoral, 42\% deste grupo não tiveram mandatos anteriores, ou seja, não tiveram a experiência eleitoral, enquanto que os $15 \%$ os quais afirmaram só usar quando necessário e os 10\% que afirmaram não utilizar por falta de recursos, já tiveram experiências anteriores e conhecem dos resultados da adoção desse tipo de instrumento durante a campanha eleitoral. Ainda 95\% deste grupo partilham da ideia de abrir a comunicação e manter sempre o contato com os eleitores, até dentro de uma visão de campanha permanente defendida por Collim e Butler (2001).

Freitas e Natali (1995) definem merchandising eleitoral ao apresentarem que é o conjunto das atividades desenvolvidas nos bairros, municípios e estados, com o objetivo de dar destaque ao candidato, gerando mais votos, ou tentando fazer com que os indecisos mudem suas posições e selecionem aquele que está em destaque. De maneira prática, o merchandising também deve ser planejado, e contido no planejamento de marketing maior, que subsidiará as ações eleitorais.

Com relação à utilização de camisas, bonés e faixas durante o período eleitoral passado, $75 \%$ dos entrevistados afirmaram que utilizaram esse item do merchandising. Apenas 5\% informaram que não utilizaram esses tipos de ações, por não ter recursos disponíveis, talvez isso tenha acontecido porque esses entrevistados já estão há mais de 8 anos na vida pública e no cargo de deputado há dois mandatos, interpretando que não é mais necessário alocar recursos para isso. Mesmo considerando o número de candidatos em 2002 que de acordo com o TRE-RN fora de 229.

Ao abordar o uso painéis em relógios urbanos, $95 \%$ dos deputados nunca utilizaram essa dessa estrutura, $35 \%$ afirmaram que não possuem recursos para esse tipo de ação, $25 \%$ disseram que não acham necessário. É uma ação interessante tendo em vista a imagem do candidato se encontra em um local de um fluxo de eleitores considerável, às vezes, pode ser entendido de forma errada e até atrapalhar a captação de votos, tudo depende de como os potenciais eleitores percebem a ação eleitoral. No item orientador de rua, que nesse estudo é considerado a equipe que trabalha durante o período eleitoral, no sentido de buscar voto e desenvolver os trabalhos nas datas que antecedem o pleito, $45 \%$ dos entrevistados afirmaram que sempre utilizam esse tipo de instrumento.

O que é realmente necessário para uma campanha em nível estadual, uma vez que existem 167 municípios no estado do Rio Grande do Norte, é que o candidato tenha pelo menos uma pequena representação, no sentido de mostrar que está presente naquele local, 25\% confirmaram que nunca utilizaram os orientadores, $75 \%$ deste grupo não tiveram outro mandato, ou seja, ganharam a eleição pela primeira vez. Deste grupo $100 \%$ são homens, e o maior destaque é que faltam recursos para esses tipos de ações integradas.

Quanto à utilização de bottons, pastas e agendas, $80 \%$ dos entrevistados afirmam que usaram esses itens na campanha, $70 \%$ deste grupo não tinham mandato anteriormente. O que pode se deduzir é que para estes deputados a força dos bottons, pastas e agendas, se destacam quando comparada com a utilização dos orientadores de rua. Dentre os motivos que fazem com que os deputados não adotassem essa estratégia de distribuição é a falta de recursos. A penúltima questão foi relacionada com os patrocínios, aqui se inclui 
o repasse de recursos para promover eventos culturais, times de futebol, festas etc., com o objetivo de conhecer se os candidatos também se preocupavam em "atacar" esses segmentos. 50\% afirmaram que nunca patrocinaram nenhuma peça teatral ou outro correlato.

Em um contraponto, apenas 5\% disseram que se utilizam dessa ação durante as eleições e $20 \%$ ratificaram que patrocinavam esses tipos de eventos. Ficando como argumento, do grupo dos 50\% que não patrocinavam esses eventos, respectivamente de 33\%, devido ausência de recursos, 37\% não acharam necessário, e 30\% externaram que nunca haviam pensado sobre o assunto antes. Pode-se assim fazer algumas considerações a respeito deste cenário. Primeiro, a equipe de assessores ou o próprio candidato não dá importância a esse tipo de atividade, ou simplesmente não pesquisaram para conhecer a real potencialidade de retorno de votos ao financiar esses tipos de eventos.

Especificamente, a utilização de sites, seja para divulgar a imagem, interagir com os eleitores, captar votos, informar as propostas etc., $50 \%$ dos entrevistados afirmaram que não utilizaram site na campanha passada, 33\% acham necessário utilizar esse tipo de ferramenta, outros 33\% não haviam pensado sobre o assunto na época e $40 \%$ disseram que utilizaram site, neste grupo todos possuem nível superior. Sterne e Priore (2001) apresentam as vantagens de se utilizar essa ferramenta de marketing, seja através da disponibilizarão de um site ou apenas de um contato eletrônico, dentre essas vantagens destaca-se: o alcance de camadas fortemente formadoras e multiplicadoras de opinião se trata de mídia com custo absoluto e relativo ainda muito baixo, oferecendo alto índice de retorno sobre investimento em comunicação, e oferta o que mídia alguma oferece: a interatividade imediata, potencializando o efeito da mensagem publicitária, se bem criada e produzida. A metade dos sujeitos desconsidera essa ferramenta.

Com relação ao uso do telemarketing na campanha por parte dos entrevistados $45 \%$ dos deputados afirmaram que utilizam na campanha passada. Apenas $25 \%$ dos sujeitos disseram não terem utilizado essa ferramenta, deste grupo $40 \%$ afirmaram que não tinham recursos para contratar esse serviço e $20 \%$ não acham necessário essa ferramenta. Percebe-se que não é dada importância à ferramenta do telemarketing ativo. Assim, ela é pouco explorada eleitoralmente, destacando que é uma ferramenta relativamente barata, que pode ser considerada como estratégica, seja na realização de pesquisas quantitativas ou auxílios nas composições dos discursos para os comícios.

Esse discurso também pode ser alimentado pela visão defendida pelo Manhanelli (1992), pois deve ser tratado nele o que foi coletado nas pesquisas de opinião qualitativa e quantitativa. Chegando assim aos tomadores de decisões de uma campanha eleitoral, por exemplo, informações consideradas pelos especialistas como confiáveis. Verificou-se que os sujeitos da pesquisa utilizaram a ferramenta de telemarketing como correspondência para os eleitores: o quantitativo de 55\% dos entrevistados afirmou que a utilizavam, pois, considera importante, já que atinge aos mais diversos eleitores. Dos $15 \%$ que disseram não utilizar, 70\% já eram deputados, provavelmente, se considerando conhecidos pelos eleitores, sendo dispensável esse tipo de ação no mercado e $70 \%$ afirmaram também que não utilizaram pela falta de recursos financeiros.

A necessidade de se ter um discurso planejado, não pode ser enquadrado como uma forma de manipulação, mas sim como estratégia para trabalhar a captação dos votos, na medida em que, durante a aparição e a comunicação com os eleitores, são comentados pontos específicos do público, município, categoria de trabalhadores etc.

Na coleta de dados verificou-se que $60 \%$ dos deputados sempre planejavam os discursos na dinâmica da interação com o eleitorado no sentido de diferenciar-se dos outros candidatos. Isso se complementa com a ênfase dada por $90 \%$ destes sujeitos na preocupação em desenvolver uma marca específica e mostrar os benefícios à população de seus trabalhos. $20 \%$ afirmou que quase sempre havia essa preocupação em preparar as falas. Os 10\% que informaram que nunca utilizam dessa ferramenta, são 100\% homens e tem acima de 50 anos de idade, somado ao fato de já terem dois mandatos como deputado estadual. 
Ao discutir se os candidatos participavam de reuniões comunitárias com outros formadores de opinião, $65 \%$ dos pesquisados informaram que participaram de reuniões na comunidade, provavelmente, com o objetivo de aumentar a rede de contatos e expandir o alcance e lembrança de sua imagem, 10\% afirmaram que nunca participaram de tais reuniões, desse grupo $100 \%$ também não utilizaram jornais, e $50 \%$ tem nível superior, $50 \%$ do mesmo grupo afirmaram que não tinham recursos para promover esses tipos de eventos sociais, por isso não os programavam.

No que diz respeito às pesquisas quantitativas e qualitativas, independendo da finalidade, ambas devem ser utilizadas, afirma Nunes (2000), dentro do contexto eleitoral de forma a se complementarem, ou seja, um focando os resultados em números da aceitação e desempenho da campanha, e a outra vindo ao encontro subsidiando o caminho e a estratégia, como forma de alimentação de informações valiosas. No contexto quantitativo, tem-se a pesquisa de opinião pública, que é a mais utilizada pelos candidatos, pois é uma pesquisa imediatista. De acordo com Ribeiro (2002) ao realizarem pesquisas de opinião pública, na busca de conhecer as necessidades, expectativas dos eleitores, suas forma de comunicação e linguagem, procura-se compreender o que ele chama de "moral social", tem como finalidade construir o discurso sobre qualquer forma de comunicação, aproximando o persuasor do persuadido, criando assim as chamadas identidades entre eles.

$50 \%$ dos entrevistados disseram que utilizaram as pesquisas quantitativas durante a última campanha, no sentido de - provavelmente - dar um direcionamento da campanha e paralelamente coletar os resultados dos esforços das equipes de trabalhos, $30 \%$ dos respondentes disseram que não se utilizaram dessa ferramenta, deste grupo, $30 \%$ consideram as pesquisas quantitativas muito caras, como não tinham recursos disponíveis não puderam contratar institutos de pesquisas e $40 \%$ disseram não achar necessário. Analisando esses resultados nota-se que 30\% marcaram a opção "outros" descrevendo que se utilizavam das pesquisas realizadas pelos partidos, por isso não fizeram estudos específicos através das pesquisas quantitativas. Do grupo que afirmou não utilizar a pesquisa quantitativa, $60 \%$ já tiveram mandatos anteriores, $90 \%$ tem idade acima de 50 anos. O que pode sugerir a não confiança também nesta ferramenta.

Quando perguntado sobre a utilização das pesquisas qualitativas durante a campanha passada (2002). $45 \%$ dos entrevistados afirmou que sempre utilizam da pesquisa qualitativa, $70 \%$ deste grupo já tem mais de um mandato como deputado, o que pode ter facilitado a adesão a está ferramenta durante o pleito de $2002,35 \%$ dos deputados contaram que não se utilizaram da pesquisa qualitativa, $60 \%$ deste grupo disseram que não acham necessário essa ferramenta. Sendo todos do sexo masculino, e $45 \%$ possuem apenas o ensino médio completo.

A última questão permeia o campo dos softwares, se os deputados utilizaram na campanha de 2002 algum sistema de informações eleitoral, que subsidia as ações eleitorais específicas, com os mais diversos tipos de informação, desde o cadastro de eleitores, políticos parceiros, passando pelos relatórios gerenciais. E em um contexto maior, alimenta o planejamento da campanha. 55\% dos entrevistados afirmaram que nunca utilizaram nenhum sistema de informação eleitoral, 33\% deste grupo disseram que não acharam necessário, 33\% disseram que não tinham recurso para programar esse tipo de ferramenta. Dentro desses $55 \%, 90 \%$ estão com idade acima de 35 anos, $95 \%$ são homens e $30 \%$ só possuem o ensino médio completo.

As relações públicas também possuem uma função elaborativa afirma Kunsch (1997), pois é um processo de exame analítico e pericial que tem por objetivos chegar a um balanço das opiniões, após realização de um levantamento cuidadoso de informações junto aos públicos de todos os segmentos de interesse, levantar o perfil real da instituição. $70 \%$ dos entrevistados afirmaram que sempre ou quase sempre utilizaram da estratégia de publicarem materiais e artigos em jornais. É um número considerado, pois existem 7 jornais circulando no estado do $\mathrm{RN}, 15 \%$ dos entrevistados disseram que não utilizam esse tipo de ferramenta por não disporem de recursos suficientes e não acharem necessário, $70 \%$ deste grupo (15\%) possuem acima de 50 anos, 100\% não possuíram sites, nem se utilizaram do telemarketing ativo. 
Os sujeitos de pesquisas concorrem a cargos ao legislativo, não é comum encontrar emissoras de Tv ou rádio que promovam debates, até por uma questão do número de candidatos ser elevado, dificultando a logística. Mesmo assim, existem outras oportunidades que são as entrevistas com os jornalistas, nos mais diversos meios impressos e televisivos. Nesse item foi questionado aos deputados se eles participaram de entrevistas na Tv e no rádio, o quantitativo de $70 \%$ dos entrevistados afirmou que utilizaram desse mecanismo, 5\% disseram que nunca utilizaram, neste grupo estão os que participaram pela primeira vez de uma campanha eleitoral e suas respectivas campanhas foram trabalhadas no interior do estado.

Dando sequência as ferramentas, está a sua participação em eventos. Dentro da perspectiva de se manter presente, desde uma festa comunitária, uma participação em uma colação de grau, ou uma festa de gala. Respeitando as particularidades de cada local e a postura do candidato nas mais diversas situações, $45 \%$ dos entrevistados afirmaram que sempre vão a eventos durante o período eleitoral, com o intuito principal de se fazer presente sempre, $10 \%$ dos deputados disseram que não vão a eventos no período eleitoral, talvez devido à noção que as pessoas podem ter ao associar a imagem do deputado em eventos somente em período eleitoral.

Quando de trata de publicação de revista própria, 40\% dos entrevistados informaram que não utilizaram esse tipo de publicação, neste grupo 30\% atrela a não publicação à ausência de recursos, e outro grupo de 30\% não achou esse tipo de ferramenta interessante (necessária), 90\% do grupo que não utilizam esse tipo de ação tem idade acima de 50 anos. Mais uma vez, esse grupo apresenta um foco diferente no que tange à propagação de mensagens em meios impressos.

Conforme defende Ribeiro (2000) deve existir uma necessidade que se trabalhe a campanha do futuro, dentro do cenário da segmentação, o que o autor denomina da "desmassificação" das campanhas. Principalmente, espera-se trabalhar dentro do contexto da campanha permanente apresentada por Collim e Butler (2001) ao defenderem que o marketing político não existe (é percebido) somente durante as campanhas políticas eleitorais, o que certamente se tem é o chamado marketing político dentro de uma nova denominação: a campanha permanente, ou seja, os esforços eleitorais aparecem e são mais chamativos no período da campanha. E ao se ter o mercado previamente segmentado, o que tem a uma facilidade maior do desenvolvimento das ações integradas eleitorais, uma vez que trabalha dentro do contexto de foco.

Quanto aos resultados do questionamento de como os candidatos administravam seus trabalhos no estado - durante a campanha - e se eles segmentavam o mercado alvo a ser estruturado estrategicamente, o que percebe é que os candidatos não tem uma visão definida do que é segmentação de mercado e posicionamento nesse segmento embora $40 \%$ afirmaram, que usaram a segmentação quando achavam interessante, dos 15\% que disseram que não terem adotado a segmentação não o fizeram por não achar necessário. Isso se ratifica, tanto nos dados quantitativos, como na entrevista quando eles foram questionados se na campanha passada houvera uma preocupação de trabalhar em segmentos as ações, logo abaixo segue algumas transcrições destas entrevistas.

“...Aqui eu represento alguns segmentos, as categorias hoje sentem a necessidade de terem representação na assembleia. Aqui eu sou bancário e contabilista e solicito o voto de meus colegas. Cada vez que eu foco um segmento faz-se necessário que eu foque a mensagem para aquele determinado público. O candidato tem que esta por dentro da realidade dos segmentos, e deve estar muita bem informada. A questão da segmentação é importante..."; Sujeito C

“...Eu segmento o trabalho sim, (exemplo: o sujeito em um comício pediu as crianças que ela pedisse aos seus pais que eles vestissem o boné e a camisa).Também trabalho com os idosos, eles me adoram, os jovens da classe média me olham com inveja, e os jovens carentes tem vergonha de mim. Eu sei que os trabalhos ,a comunicação e as ferramentas devem facilitar a campanha...” ;Sujeito D 
"... Segmentei todo o trabalho na zona norte da cidade. Assim eu segmentei com o slogan 100\% zona norte..."; Sujeito E

“... Não, a gente define em toda campanha quais são os setores que nos trabalhamos, não os setores somente para a campanha, mas aqueles que já temos um certo relacionamento..."; Sujeito F

“... trabalhamos de forma geral para todo mundo, sem se preocupar em tratar as pessoas de forma diferente..."; Sujeito G

' ... De forma geral e evidente que não se pode chegar a todos os segmentos, ai você deve priorizar que segmentos teriam uma maior aceitabilidade. Onde ele já tem uma certa referência, então em cada segmento apenas ajustar um pouco a linguagem. sendo fiel a mensagem de toda a campanha. Quando o meio de comunicação deve ser profissionalizado..." Sujeito K

O que pode ser entendido, é que os deputados não possuem definido, o conceito, a importância e o mecanismo da segmentação do mercado na íntegra, dentro da busca em facilitar os trabalhos eleitorais e minimizar os gastos, uma vez que já se tem definido previamente, conforme afirma o Sujeito E, pois ele sabe que vai alocar os recursos mais intensamente para aquela região determina por ele como a principal dentro da proposta maior de sua candidatura. Em outro extremo, encontra-se o sujeito A, que afirmou não trabalhar com segmentação, talvez ele e sua equipe não o façam de forma consciente, mas existe uma possibilidade que os trabalhos sejam feitos através de pequenas segmentações.

Os sujeitos C e D possuem claramente a formatação do conceito Segmentação e posicionamento. Mas percebe-se que não há uma ênfase em se posicionar em cada segmento, conforme descreve o sujeito G: "trabalho de forma geral para todo mundo". O sujeito K, demonstrou um conhecimento mais especifico da finalidade da segmentação e o mais importante possui o discernimento de até que ponto atacar um segmento e interessante e viável, do ponto de vista de marketing logístico e financeiro.

Sabe-se que também é feita, na maioria das vezes, pelos partidos políticos um cadastro atualizado de eleitores, e até de eleitores em potenciais. Nesse questionamento aos candidatos, buscou-se identificar se havia uma preocupação em conhecer seu eleitorado de forma dinâmica e atualizada, $45 \%$ dos deputados entrevistados disseram que sempre utilizam um cadastro de eleitores atualizados e $45 \%$ afirmaram que quase sempre na campanha passada se utilizou de cadastro de eleitores.

No cenário atual, com bem afirma Giglio (1996), o marketing funciona um conjunto de ações orientadas para o cliente (eleitores) que tem como retaguarda o marketing integrado, visando gerar a sua satisfação e bem estar em longo prazo, como chave ara o atingimento das metas organizacionais (metas da campanha). Nessa sequência, encontra-se a necessidade de se conhecer o comportamento do consumidor, seja para saber onde podem ser melhorados os processos, ou na busca pela satisfação contínua.

Nessa pergunta feita aos deputados procurou-se conhecer se havia uma troca de informações com os municípios considerados estratégicos (definidores de um pleito) sobre o comportamento desses eleitores, que são os consumidores do produto, ou seja, o candidato. Apenas $20 \%$ dos pesquisados informaram que sempre trocam informações com os municípios estratégicos, com o intuito de tomar ciência de como atuar nesta ou naquela região $100 \%$ deste grupo são homens e $95 \%$ tem idade acima de 50 anos, todos já possuem mais de dois mandatos como deputados estaduais. Evidencia-se que nos $60 \%$ que afirmaram nunca terem trocado informações com os municípios estratégicos sobre os eleitores, sendo assim profundo desconhecedores de informações orientadoras na campanha ou até fora dela, $70 \%$ deste grupo informou anteriormente que trabalhavam com correspondências para os eleitores, o que se leva a crer que existe uma preocupação de informar aos eleitores (passar a mensagem), mas não de captar o resultado dessas ações, uma vez que, não existe um foco em conhecer também o comportamento desses eleitores. Essa 
observação se ratifica ainda mais quando $70 \%$ deste grupo afirmaram ter utilizado o telemarketing, mas - provavelmente - dentro da mesma ideia de passar informações e conquistar aceitações, e não entender também o comportamento dos eleitores, ao longo da campanha.

Na discussão sobre a análise, segmentação e posicionamento do mercado, que tinha como objetivo captar dos candidatos o que Grandi, Marins e Falcão (1992) e Lima (2002) afirmaram que se deve desenvolver uma estrutura de marketing político preocupado com a imagem, em longo prazo. Essa filosofia de campanha permanente já pode até existir entre os candidatos, pelo menos, ainda no processo de conceituação. $90 \%$ dos deputados entrevistados fazem visitas a municípios denominados de estratégicos após o período eleitoral. Isso se evidencia mais ainda com a transcrição da fala do sujeito I, logo abaixo.

"Na verdade eu estou aqui conversando com você e já estou em campanha" Sujeito I

Na entrevista realizada com os 19 deputados, procurou-se identificar dentro dos achados gravados/ transcritos, como eles entendem o marketing eleitoral e político, a questão do planejamento eleitoral, a utilização da tecnologia da informação na campanha, e outras variáveis inerentes ao processo eleitoral. Conforme técnica escolhida para tratar os dados de forma qualitativa, fora a análise de conteúdo proposta por Bardin (1997) adaptado para essa pesquisa. Das 11 perguntas realizadas aos sujeitos de pesquisa, podese chegar à definição categorias, que formatam o composto maior da coleta dos dados nessa abordagem. Nessa categoria, teve-se o propósito maior de entender como eles diferenciam os dois tipos de marketing apresentados pela literatura. Dentre as subcategorias que mais de destacaram tem-se:

- Não uso o marketing eleitoral nem político, e não compactua com essa ideia de campanha permanente;

- A separação entre os conceitos acontece devido ao aspecto temporal;

- Ambos buscam a permanência na esfera pública;

- O marketing político é técnico e o eleitoral é prático;

- Um vende o candidato o outro se preocupa com a imagem no longo prazo;

- A preocupação de ambos é a propaganda do candidato;

- Não vejo muita bem a diferença entre eles;

- O marketing político prepara o eleitoral.

Percebe-se que existe um conceito de marketing eleitoral e político nas respectivas visões dos sujeitos de pesquisas. Mas, a ideia apresentada por eles ainda pode ser - em sua maioria - inequívoca, pois resumem essa diferença através de conceitos de propaganda e criação de imagem somente.

Rech (2000) define marketing político como um conjunto de técnicas e procedimentos cujo objetivo é avaliar através de instrumentos de pesquisa e outros meios para tomar decisão no que diz respeito ao planejamento para alcançar os resultados esperados, ou seja, a vitória. Para os sujeitos de pesquisa, o marketing político se preocupa com a imagem e também com a propagação dos trabalhos alcançados na assembleia. Ao tecerem esses comentários eles restringem, o marketing político a propaganda, quando se sabe que a atividade também é estudada por incluir o comportamento do eleitor. Na ligação entre objetivos políticos e necessidades sociais está implícito o conceito de relação social de troca, uma das remissas fundamentais de marketing, segundo Kotler (2002).

A ideia da venda proposta por alguns, ao definirem o marketing eleitoral, merece ser destacada uma vez que, no encaminhamento das ações espera-se não que o candidato seja vendido, mas indistintamente comprado (ele, sua proposta e suas ideias) pelos eleitores. Isso se expande quando um dos sujeitos de pesquisa afirma que o marketing político é técnico e o eleitoral é prático. O que na verdade não é possível fazer essa distinção em um cenário, onde ambos são práticos e técnicos, uma vez que muitas 
das ferramentas do marketing eleitoral pesquisadas neste paper, também podem ser utilizadas pelo marketing político.

Manhanelle (1992) defende que o marketing eleitoral surgiu em paralelo com o marketing político, é como se existisse foco distinto, mas sempre como o mesmo objetivo final, ganhar um pleito, ou permanecer na cadeira que ocupa. Uma vez que é sensível a necessidade de juntar as ações eleitorais com as ações governamentais (dentro do contexto ético), com a ideia de simultaneidade.

$\mathrm{Na}$ formulação do composto Rech (2000), Figueiredo (1994) Kotler (2000), Richers (2000) e Manhanelle (1992), destacam o preço, que no foco deste estudo é a ideia do candidato que deve ser comprada pelos eleitores, que eles não passem por um processo de dissonância cognitiva, após verem seu candidato assumindo o cargo e começando os trabalhos. O marketing político deve funcionar como um anteparo (e ainda mais como uma filosofia de trabalho) para toda em qualquer ação governamental e até eleitoral, seja com os eleitores, outra esfera pública ou privada etc.

Outra análise importante ainda dentro do contexto da entrevista está relacionada com o comportamento do candidato, na busca de tentar conhecer deles como foi e é o comportamento durante uma campanha eleitoral e após o término da mesma. Principalmente, nos itens relacionados como posicionamento, forma com que se comporta antes durante a após a campanha eleitoral, como é a relação com os eleitores etc. Dentre os itens que mais se destacaram no resultado final da análise tem-se:

- Não mudo, eu sou a mesma pessoa antes, durante e depois da campanha;

- A relação com o eleitor se intensifica durante o pleito;

- A forma como eu sou percebido é medido através do contato pessoal, e pesquisas em geral;

- As pessoas me veem como homem ligado à área social (saúde, educação etc.);

- O meu comportamento muda durante o período eleitoral;

- A questão tempo dificulta um contato maior com o eleitor;

- Informo os resultados de todas as solicitações dos eleitores;

- O "fogo" da campanha muda a minha pessoa;

- Utilizamos telefone, cartas e/ou pessoalmente as reivindicações;

- O meu comportamento não mudou, o que muda é minha agenda; e

- É impossível manter o contato com todos os eleitores, por isso foco na liderança.

A imagem que deve ser criada por parte do pleiteante deve ser gerenciada, como lembra Kotler (1994), através do marketing de imagem, adaptado a um contexto político-eleitoral. $\mathrm{O}$ candidato define que imagem quer que seu público e sociedade o perceba e o identifique, determina que tipos de ferramentas podem ser utilizadas e ações a serem implementadas. Isso está relacionado com o posicionamento, o que Rego (1985) define como técnica de auxilio mercadológico. Como se percebe, o comportamento da maioria dos sujeitos de pesquisa não muda durante o período eleitoral. Segundo as entrevistas, eles, na sua maioria, são as mesmas pessoas antes, durante e depois de uma campanha eleitoral. Isso pode ser identificado, pois de acordo com Figueiredo (1986) ao afirmar que uma campanha é uma peça de comunicação, e sem comunicação que é uma das mais perceptíveis formas de expressar comportamentos, o candidato dificilmente se elege.

A questão da comunicação parece ser imprescindível nesse processo, no que se refere às solicitações dos eleitores durante a campanha eleitoral, a maioria recebem suas respostas, sejam pessoalmente, correspondência e outros meios de comunicação. Abrindo o leque durante a entrevista foi questionado também se após a entrada na assembleia do estado do RN, como acontece esse feedback. A maioria disse, veementemente, que continuam a responder, sejam ideias, solicitações, projetos de leis e requerimentos, com a mesma franqueza do período eleitoral. Isso quando trabalhado como ferramenta de relacionamento 
pode desembocar em uma conquista maior de votos e potenciais votos através da prospecção eleitoral.

A comunicação é algo imprescindível em um processo eleitoral, e também, deve conciliar com tudo o que o candidato trata com a sociedade, assim as mensagens emitidas por ele devem está sempre dentro do contexto do que ele propõe, não fugindo de suas ideias, convicções e propostas (CHEN e CHEN, 2003). Por isso, foi questionado aos deputados se eles planejavam os discursos para os comícios, $60 \%$ deles afirmaram que era adaptado para o local e hora onde iria acontecer o pronunciamento, enquanto apenas $10 \%$ nunca utilizou dessa estratégia, desse grupo, $100 \%$ já tiveram dois mandatos e estão acima de 50 anos de idade, já ocuparam cargos públicos como o de vereador e prefeito, e só possuem o ensino médio completo.

Nesse cenário, não se pode afirmar com certeza se existe uma relação direta entre nível de escolaridade, $50 \%$ destes sujeitos nunca utilizaram do telemarketing ativo, ou seja, subentende-se que não preparavam seus discursos previamente eram apenas improvisavam, 65\% participam de reuniões comunitárias, como uma forma de estar presente na comunidade. Essa presença dentro de um contexto eleitoral suporta uma busca por um número maior de votos, e no contexto político trata de uma forma de manter os contatos com a população e certamente dentro da estratégia de formatar uma marca específica na mente dos eleitores, extrapolando e trabalhando dentro da filosofia da campanha permanente. Com esses pequenos ajustes, provavelmente, as estruturas das campanhas eleitorais não seriam tão caras, uma vez que a preocupação, não seriam somente angariar mais e mais voto, mas sim trabalhar com os conquistados através das mais diversas ferramentas do marketing.

Para os autores Semenik e Bamossy (1996), todos os elementos que estão envolvidos no processo de decisão da gestão do marketing que proporcionam à empresa uma base para resposta ao ambiente externo e ao mesmo tempo a própria regulação da estrutura da instituição, uma que se destaca sem dúvida alguma é a segmentação de mercado. No contexto eleitoral, isso é ainda mais perceptível, devido à instabilidade do comportamento do consumidor (eleitor) que agora não "compra" um produto, mas sim a base de uma ideia, a imagem do candidato etc. Na verdade a pesquisa nos apresenta através da abordagem qualitativa (textos transcritos logo abaixo), que a maioria dos entrevistados não possui um conceito para segmento, talvez na adote esse tipo de estratégia de marketing por ausência de orientação.

“... Não trabalhamos com segmentação de mercado..."; Sujeito A

“... Não, não existe segmentação, eu faço o trabalho baseado na minha história. Não temos essa preocupação de separar grupos não...”; Sujeito B

“... trabalhamos de forma geral para todo mundo, sem se preocupar em tratar as pessoas de forma diferente..."; Sujeito G

Essa afirmação fica evidenciada quando $65 \%$ dos entrevistados somente utilizam quando necessário ou raramente a segmentação. O que deveria ser uma constante dentro do cenário atual. Mas, existe um dado interessante, $90 \%$ sempre ou quase sempre utilizam de cadastro de eleitores atualizados, contudo, não para implementar ações concatenadas com os objetivos maiores do marketing político e eleitoral, e sim para fazer ações pontuais, $90 \%$ nunca utilizou um cadastro de políticos parceiros, mesmo sabendo que existem várias mudanças de partido e $60 \%$ também nunca utilizou da ferramenta de troca de informações sobre o comportamento do consumidor, nos diversos municípios, $75 \%$ nunca monitorou a concorrência durante e após o período eleitoral.

Desta forma, pode-se entender que as campanhas eleitorais são realizadas um pouco fora do contexto das ferramentas do marketing, uma vez que, desconsidera pontos básicos. Dentro de um estado onde 
se tem mais de 100 municípios, é importante e extremamente necessário que existam informações, e principalmente caso os entrevistados desejem permanecer nos seus respectivos cargos e até almejam outro de maior amplitude.

\section{CONSIDERAÇÕES FINAIS}

O Marketing Político vem se consolidando, cada vez mais, como peça fundamental no processo eleitoral, para garantir uma campanha estruturada e eficiente. Um dos principais objetivos do marketing voltado para a política é justamente situar de forma positiva os candidatos junto aos seus eleitores e outro tipo de público. O trabalho do Marketing Político é garantir a eleição dos seus clientes e/ou a manutenção de sua imagem, antes, durante e depois do mandato.

O deputado potiguar, em sua maioria, não tem incorporado claramente o conceito de marketing eleitoral na sua essência, dentro da sua estrutura de trabalho nas campanhas eleitorais, muito menos dentro da ótica longitudinal do marketing político, o qual requer uma ação mais permanente através do tempo. A grande preocupação da maioria dos entrevistados está centrada na conquista do voto no curto prazo, sem a necessária preocupação com o marketing de relacionamento, ou seja, estabelecendo ações e vínculos duradouros com seus eleitores. $\mathrm{O}$ foco não é aparecer apenas como forma de conquista localizada de votos, mas sim criar um contexto de permanência na mente dos eleitores.

$\mathrm{O}$ uso da maior ferramenta do século XX, a internet, também está muito restrita entre os deputados potiguares. Poucos são os que a utilizam como meio de comunicação barato e eficiente com os eleitores e sociedade. A comunicação tradicional, ou seja, o uso da correspondência ainda surge como alternativa mais utilizada (podendo caracterizar uma falha no contexto da segmentação, por exemplo.). Talvez por um desconhecimento do alcance da grande rede, ou então por considerar algo caro, e no limite por serem avessos à tecnologia. Outro ponto detectado é o não interesse em estudar previamente o comportamento do eleitor de forma sistemática, o que poderia vim a ser uma das soluções para os investimentos desnecessários em uma campanha.

Em suma, por adotarem uma visão de curto prazo para fins eleitorais versus uma visão de longo prazo com objetivos de programarem e fixarem uma imagem positiva e de ações permanentes no cognitivo dos eleitores e sociedade em geral, os políticos potiguares se contentam, na sua parcela expressiva, em trabalhar dentro da filosofia de vendas. A ideia simples de se apresentarem à sociedade com uma bagagem de truques e artifícios de comunicação, sem a preocupação de sedimentarem um relacionamento autossustentável. Afinal, não se pode tratar o marketing político e eleitoral apenas como uma questão de imagem. A garantia da sobrevivência do político em longo prazo passa pela transformação do consumidor em cliente proativo. Aqueles que não perceberem esta perspectiva, provavelmente, não sobreviverão no mercado eleitoral.

\section{REFERÊNCIAS}

ALMEIDA, Sérgio. Cliente eu não vivo sem você. 12.ed. Salvador: Casa da qualidade, 2000.

ARANHA, Francisco. Sistemas de Informação Geográfica: Uma arma estratégica para o database marketing. RAE - Revista de Administração de empresas. São Paulo, v.36, n.2, p-12-15, abr/mai/jun. 1996.

BARDIN, Laurence. Análise de conteúdo. Trad. Luis Antero Reto e AugustoPinheiro.Lisboa/Portugal: Edições70, 1977. 
COLLINS Neil; BUTLER, Patrick, Payment on delivery - Recognising constituency service as political marketing. European Journal of Marketing. v. 35 N. 9 pgs 1026-1037, 2001.

CHEN, Chun-Fu CHEn Jaw Minh. The construction of electoral marketing modes in Taiwan.Poole. v.1. 20, Iss. 2 pg. 143, 13 p., jun 2003

CHURCHILL, Gilbert A, PETER, J Paul. Marketing: Criando valor para os clientes . São Paulo: Saraiva, 2000.

DRUCKER, Peter. As informações de que os executivos realmente precisam. In:

Medindo o desempenho empresarial / Havard Business Review. Tradução de Afonso Celso da Cunha Serra. Rio de Janeiro: Campus, 2000. p. 9 -30

FIGUEIREDO, Carlos. Técnicas de Campanha Eleitoral. São Paulo: Ibrasa,1986.

FIGUEIREDO, R.; Malin, M. A Conquista do Voto: Como agem os especialistas nas campanhas eleitorais. São Paulo: Brasiliense, 1994.

FIGUEIREDO, Rubens. O que é Marketing Político. São Paulo: Brasiliense, 1994.

FREITAS. S Nelson. NATALI. Marcos. Merchandising na Prática. São Paulo: Ed.STS, 1995

GIL, A. C. Como elaborar o projeto de pesquisa. São Paulo: Atlas, 1987.

GIGLIO, Ernesto. O comportamento do consumidor e a gerência de marketing. São Paulo: Pioneira, 1996.

GODIN Seth. Marketing de Permissão: transformando desconhecidos em amigos e amigos em clientes . São Paulo: Campus, 2000.

GRAEML, Alexandre Reis. Sistemas de informações: o alinhamento da estratégia de TI com a estratégia corporativa. São Paulo: Atlas, 2000.

GRANDI, Rodolfo. MARINS Alexandre, FALCÃO Eduardo (Organizadores). Voto é Marketing. O resto é Política: estratégias eleitorais competitivas.São Paulo: Edições Loyola, 1992

JONES, Susan K. Estratégia criativa em marketing direto. São Paulo: Makron Books, 1993.

KOTLER, Philip. Administração de Marketing: análise, planejamento, implementação e controle. São Paulo: Atlas, 2000.

São Paulo: Futura, 2002.

, Marketing para o século XXI: como criar, conquistar e dominar mercados. 11.ed.

, HAIDER, Donald H. REIN, Irving. Marketing Público: como atrair investimentos,

Empresas e Turismo para Cidades, Regiões, Estados e Países São Paulo: Makron Books, 1994. 
Atlas: São Paulo, 1996.

Administração de marketing - Análise, Planejamento, Implementação e Controle. . TRIA DE BASES. Fernando. Marketing Lateral: uma abordagem revolucionária para criação de novas oportunidades e mercados saturados. São Paulo: Campus, 2004.

KUNSCH, Margarida M. Krohling. Obtendo Resultados com Relações Públicas..,São Paulo: Pioneira, 1997.

LAS CASAS, Alexandre L. Marketing: conceitos, exercícios e casos. São Paulo: Atlas, 4º ed 1997.

LAKATOS, Eva Maria, MARCONI, Marina de Andrade. Metodologia do trabalho científico. São Paulo: Atlas, 1986.

LIMA . Marcelo O Coutinho. Marketing Eleitoral. São Paulo: E-book, 2002.

MACHADO, Mônica. A política mercadológica. Revista SBPM, v.2, n.5, p. 53-56, maio 1998.

MCCARTHY, E. Jerome e PERREAULT, William D. Marketing Essencial: uma abordagem gerencial e global. São Paulo: Atlas, 1997.

MANHANELLI, Carlos Augusto. Eleição é guerra. São Paulo: Summus, 1992

MARLAND Alex. Marketing political soap: A political marketing view of selling candidatés like soap, of electioneering as a ritual, and of electoral military analogies. Journal of Public Affairs London:. V. 3, n. 2, p. 103. May 2003.

MATTAR, Fauze Najib. Pesquisa de marketing. 2. ed. São Paulo: Atlas,1994. v.1

MIDDLETON, Alan. The Evolution Of Marketing. Marketing Toronto. 2005, v. 110, p. 8, p. 9-11p., feb. 2005.

NUNES, Márcia C. O papel das pesquisas. In: FIGUEIREDO, Rubens et al. Marketing político e persuasão eleitoral, São Paulo: Fundação Konrad Adenauer, 2000.

OLIVEIRA, M de F. O Uso dos Instrumentos de Marketing pelos Partidos Políticos Paraibanos. Dissertação (Mestrado apresentado ao PPGA), 2000.

PORTER. M E.Vantagem Competitiva : criando e sustentando um desempenho superior. Tradução: Elizabeth Maria de Pinto Braga. Rio de Janeiro: Campus, 1990

RECH, Roberto Dalpiaz. Marketing Político: seja diferente e conquiste as vitórias nas eleições municipais. 2.ed.Porto Alegre: Imprensa Livre, 2000.

REDONDO. Wagner. Planejamento de uma campanha política. 3.ed. São Paulo: Fundação Biblioteca Nacional,1993. 
REGO, Francisco Gaudêncio Torquato do. Marketing político e Governamental: um roteiro para campanhas políticas e estratégias de comunicação. 3.ed. São Paulo: Summus,1985.

REY González. Pesquisa Qualitativa em Psicologia: caminhos e desafios. São Paulo: Pioneira Thonsom, 2002.

RIBEIRO, Rodrigo Mendes. Marketing político: o poder da estratégia nas campanhas eleitorais. Belo Horizonte: Editora C/Arte, 2002.

RICHERS, Raimar. Marketing: uma visão brasileira. São Paulo: Negócio Editora, 2000.

RIES, Al \& TROUT, Jack. Marketing de guerra. São Paulo: Makron Books, 1986.

ROESCH, Sylvia Maria Azevedo. Projetos de estágios e de pesquisa em administração: Guia para estágios, trabalhos de conclusões, Dissertações e estudos de caso. 2.ed. São Paulo, Atlas. 1999.

SALLES. Luiz C Lucas. Marketing político na última década do século XX: um estudo de caso das estratégias adotas nas campanhas estaduais para o Governo da PB. (Dissertação de Mestrado) UFPB PPGA, 2000.

SAMPAIO Rafael, Propaganda de A a Z: Como usar a propaganda para construir marcas e empresas de sucesso, Campus, ABR, Rio de Janeiro, 1997.

SCHEWE, Charles D; SMITH Reuben M. Marketing: conceitos, casos e aplicações.São Paulo: Editora McGraw-Hill do Brasil,1982.

SEMENIK, Richard J. e BAMOSSY, Gary J. Princípios de Marketing: uma perspectiva global.São Paulo: Makron Books, 1996.

STERNE Jim; PRIORE Anthony E-mail Marketing: Utilizando o e-mail para atingir seu públicoalvo, conquistar e manter clientes fiéis. São Paulo: Makro, 2001.

VAZ. Gil Nuno. Marketing Institucional: o mercado de idéias e imagens. São Paulo: Pioneira,1995.

VERGARA, Sylvia Constant. Projetos e relatórios de pesquisa em administração. 2.ed. São Paulo: Atlas. 1998. 